Marquette University

e-Publications@Marquette

Biomedical Sciences Faculty Research and

Publications

Biomedical Sciences, Department of

7-1-2011

Serotonin mediated changes in corticotropin releasing factor mRNA expression and feeding behavior isolated to the hypothalamic paraventricular nuclei

Joanne P. Boisvert

Marquette University

Tyler J. Boschuetz

Marquette University

Jon M. Resch

Marquette University, jon.resch@marquette.edu

Christopher R. Mueller

Marquette University

Sujean Choi

Marquette University, sujean.choi@marquette.edu

Accepted version. Neuroscience Letters, Vol. 498, No. 3, (July 2011): 213-217 . DOI. (C 2011 Elsevier. Used with permission. 


\title{
Serotonin Mediated Changes in Corticotropin Releasing Factor mRNA Expression and Feeding Behavior Isolated to the Hypothalamic Paraventricular Nuclei
}

\author{
Joanne P. Boisvert \\ Department of Biomedical Sciences, Marquette University, \\ Milwaukee, WI \\ Tyler J. Boschuetz \\ Department of Biomedical Sciences, Marquette University, \\ Milwaukee, WI \\ Jon M. Resch \\ Department of Biomedical Sciences, Marquette University, \\ Milwaukee, WI \\ Christopher R. Mueller \\ Department of Biomedical Sciences, Marquette University, \\ Milwaukee, WI \\ SuJean Choi \\ Department of Biomedical Sciences, Marquette University, \\ Milwaukee, WI
}




\begin{abstract}
Fenfluramine reduces hunger and promotes body weight loss by increasing central serotonin (5-HT) signaling. More recently, neuropeptides have been linked to the regulation of feeding behavior, metabolism and body weight. To examine possible interactions between $5-\mathrm{HT}$ and neuropeptides in appetite control, fenfluramine (200 nmol/0.5 $\mu \mathrm{l} /$ side) was administered directly into the hypothalamic paraventricular nuclei (PVN) of male rats. Bilateral fenfluramine produced significant hypophagia and increased expression of PVN corticotropin releasing factor (CRF) mRNA and neuropeptide $Y$ (NPY) mRNA in the arcuate nucleus within the first hour after drug administration. Fenfluramine's effects on feeding behavior and mRNA expression were blocked by PVN injections of a $5-\mathrm{HT}_{1-2}$ receptor antagonist, metergoline (15 nmol/0.5 $\mathrm{ll} / \mathrm{side})$. These data suggest that $5-\mathrm{HT}$ neurons targeting hypothalamic paraventricular CRF neurons may participate in an appetite control circuit for reducing food intake.
\end{abstract}

Keywords: serotonin, corticotropin-releasing factor, hypothalamus, appetite, mRNA

\title{
Introduction
}

Drugs used clinically to reduce appetite and body weight typically manipulate catecholamine and/or serotonin (5-HT) signaling [3]. One such agent, fenfluramine, which was very effective but is no longer used clinically [7], is still employed as a research tool to examine the role of $5-\mathrm{HT}$ neurons in appetite control because it produces a potent and highly selective stimulation of $5-\mathrm{HT}$ transmission [10]. Increasing $5-\mathrm{HT}$ synaptic transmission using agents like fenfluramine decreases appetite and feeding behavior in both animals and humans $[12,24]$. Although the regulation of feeding behavior by $5-\mathrm{HT}$ is extensively well documented, the mechanisms or central pathways that mediate this behavior are still poorly understood.

Numerous 5-HT receptor subtypes are located in the hypothalamus, a brain region which participates in the control of feeding and metabolism. The hypothalamic paraventricular nuclei (PVN) contain moderate to abundant levels of $5-\mathrm{HT}_{2 \mathrm{~A}}$ and $5-\mathrm{HT}_{1 \mathrm{~B}}$ receptor subtypes, for example, whereas the arcuate nuclei contain significant quantities of the $5-\mathrm{HT}_{2 \mathrm{C}}$ receptor $[6,8,22]$. Agonists to these specific receptor subtypes can suppress food intake while antagonists block such actions [16, 31, 34]. Given the anatomical distribution of these receptors, interactions with hypothalamic neuropeptides known to alter appetite and feeding behavior become a strong candidate for a mechanism of action of 5-HT-mediated hypophagia. PVN neurons containing corticotropin releasing factor (CRF), a neuropeptide that suppresses feeding behavior, receive

Neuroscience Letters, Vol. 498, No. 3 (July 2011): pg. 213-217. DOI. This article is (C) Elsevier and permission has been granted for this version to appear in e-Publications@Marquette. Elsevier does not grant permission for this article to be further copied/distributed or hosted elsewhere without the express permission from Elsevier. 
brainstem raphe 5 -HT inputs and become activated following systemic fenfluramine administration $[17,20]$. While current approaches to identify mechanisms of appetite regulation have focused heavily on neuropeptides as appetite signaling molecules [30], more recent lines of research have begun to explore for possible interactions between monoamine (e.g., 5-HT) and neuropeptide neurons in appetite regulation $[14,28]$.

Prior studies have demonstrated that systemic fenfluramine in rats produces a rapid-onset hypophagia (30-60 min) and a concomitant increase in PVN CRF mRNA levels $[4,18]$. To determine whether this change in CRF mRNA expression is a direct or indirect action of 5-HT transmission, we administered fenfluramine directly into the PVN, alone or after administering a 5-HT receptor antagonist, and measured subsequent changes in food intake and the mRNA expression of hypothalamic neuropeptides known to influence feeding.

\section{Materials and Methods}

\section{Animals}

Adult male Sprague-Dawley rats (225-250 g; Harlan, Indianapolis, IN) were housed singly on a $12 \mathrm{~h}$ light/dark cycle and provided food (Harlan 8604) and water ad libitum. Daily food intake was measured remotely with a BioDAQ Food Intake Monitor (Research Diets, New Brunswick, NJ). Feeding bouts measured the number of times animals physically manipulated the food hopper and removed food. The duration of a bout was defined as a single episode of feeding in which no inter-feeding interval exceeded 15 seconds. The Marquette University Institutional Animal Care and Use Committee approved all experiments and procedures.

\section{Surgery}

Animals were anesthetized with a rodent cocktail consisting of ketamine/xylazine/acepromazine (77/1.5/1.5 mg/ml/kg; ip) and placed in a stereotaxic apparatus. Bilateral guide cannulae (PlasticsOne, Roanoke, VA) were placed $1 \mathrm{~mm}$ dorsal to the hypothalamic PVN and secured with an acrylic resin. Stereotaxic coordinates for the PVN were: anterior/posterior, $-1.6 \mathrm{~mm}$ from bregma; medial/lateral, $\pm 0.5 \mathrm{~mm}$ from midline; dorsal/ventral, $8.4 \mathrm{~mm}$ from surface of skull [27]. Correct cannulae placements (cannulae tracks $1 \mathrm{~mm}$ dorsal to the PVN) were confirmed at the conclusion of the experiments on Nissl stained sections.

Neuroscience Letters, Vol. 498, No. 3 (July 2011): pg. 213-217. DOI. This article is (C) Elsevier and permission has been granted for this version to appear in e-Publications@Marquette. Elsevier does not grant permission for this article to be further copied/distributed or hosted elsewhere without the express permission from Elsevier. 
NOT THE PUBLISHED VERSION; this is the author's final, peer-reviewed manuscript. The published version may be accessed by following the link in the citation at the bottom of the page.

\section{In situ hybridization}

During the light phase, brains were rapidly removed, cut into 12 $\mu \mathrm{m}$ coronal sections and stored at $-80^{\circ} \mathrm{C}$ until post-fixed. Standard in vitro transcription methods were used to generate riboprobes against CRF (Mayo, Evanston, IL), NPY (Sabol, Bethesda, MD) and POMC (Wilkinson, Seattle, WA). Sections were hybridized overnight at $55^{\circ} \mathrm{C}$ with each ${ }^{33} \mathrm{P}$-labeled riboprobe.

After hybridization, slides were stringently washed in $0.5 x$ SSC for 30 min at $65^{\circ} \mathrm{C}$ (CRF, NPY) or $68^{\circ} \mathrm{C}$ (POMC) then dipped in Kodak autoradiographic emulsion NTB (Rochester, NY) and exposed for 11-22 days depending on the specific riboprobe to produce silver grains.

\section{Image analysis}

Semi-quantitative analysis of silver grains was conducted using dark field microscopy (Axioskop-2, Zeiss, Thornwood, NY) and Axiovision image analysis software (Zeiss, Thornwood, NY). Optical transmission (OT) was determined from the integration of scattered light captured with a 5x objective and analyzed for intensity of region of interest and total area of reflected light. Background values were subtracted from all measurements.

\section{Radioimmunoassay}

Trunk blood, following rapid decapitation, was collected within the first 6 hours of the dark phase in Experiment 1, whereas blood was collected just after lights off in Experiment 2. Corticosterone levels were quantified using a commercial kit (MP Biomedicals, Solon, $\mathrm{OH}$ ).

\section{Statistical analysis}

Data are presented as means \pm standard errors of the mean, and were analyzed statistically by analysis of variance (with repeated measures when appropriate). When necessary, centering data on their mean values or natural log transforms were performed prior to analysis. Fisher's analysis was used for all post-hoc group comparison. Statistical analyses were performed using StatView (SAS Institute, Cary, NC). 
NOT THE PUBLISHED VERSION; this is the author's final, peer-reviewed manuscript. The published version may be accessed by following the link in the citation at the bottom of the page.

\section{Experiment 1 - Time course of fenfluramine-induced responses}

One week after surgery, animals ( $n=94$ total; $n=8-10 /$ group) received bilateral injections of dl-fenfluramine (Sigma, St. Louis, MO; $200 \mathrm{nmol} / 0.5 \mu \mathrm{l} / \mathrm{side})$ or sterile saline $(0.5 \mu \mathrm{l} /$ side $)$ at the dorsal borders of the paraventricular nuclei. This volume and dose of dlfenfluramine administered into the PVN effectively inhibited norepinephrine-induced feeding [35].

All injections were administered during the light period 2 hours prior to dark and in awake animals but measures of food intake and tissue collection occurred at 1, 2, 4, 8, and 24 hours post-injection. In a parallel group of animals, brains and trunk blood were collected following rapid decapitation 1 , 2, or 4 hours after injections. These animals had no further access to food from the time of drug injection.

\section{Experiment 2 - Blocking fenfluramine action in the PVN}

One week after surgery, animals ( $n=32$ total; $n=7 /$ group) received two bilateral injections of fenfluramine, metergoline, or vehicle at the dorsal borders of the paraventricular nuclei. Rats initially received an injection of the $5-\mathrm{HT}_{1-2}$ receptor antagonist, metergoline (Sigma, St. Louis, MO) $(15 \mathrm{nmol} / 0.5 \mu \mathrm{l} /$ side) or vehicle $(1 \% \mathrm{~L}-(+)-$ tartaric acid, $0.5 \mu \mathrm{l} / \mathrm{side}$ ) followed by either dl-fenfluramine ( 200 $\mathrm{nmol} / 0.5 \mu \mathrm{l} / \mathrm{side}$; Sigma St. Louis, MO) or vehicle (sterile saline, 0.5 $\mathrm{\mu l} / \mathrm{side}$ ). Food was removed two hours prior to drug administration. Drugs were administered just prior to the onset of dark followed by the immediate return of food.

\section{Results}

\section{Experiment 1 - Time course of fenfluramine-induced responses}

PVN fenfluramine injections produced a rapid hypophagic response, with significant main effects for both treatment and time (repeated measures ANOVA). Food intake reduction was evident up to 2 hrs post-injection (fig. 1).

Neuroscience Letters, Vol. 498, No. 3 (July 2011): pg. 213-217. DOI. This article is (C) Elsevier and permission has been granted for this version to appear in e-Publications@Marquette. Elsevier does not grant permission for this article to be further copied/distributed or hosted elsewhere without the express permission from Elsevier. 


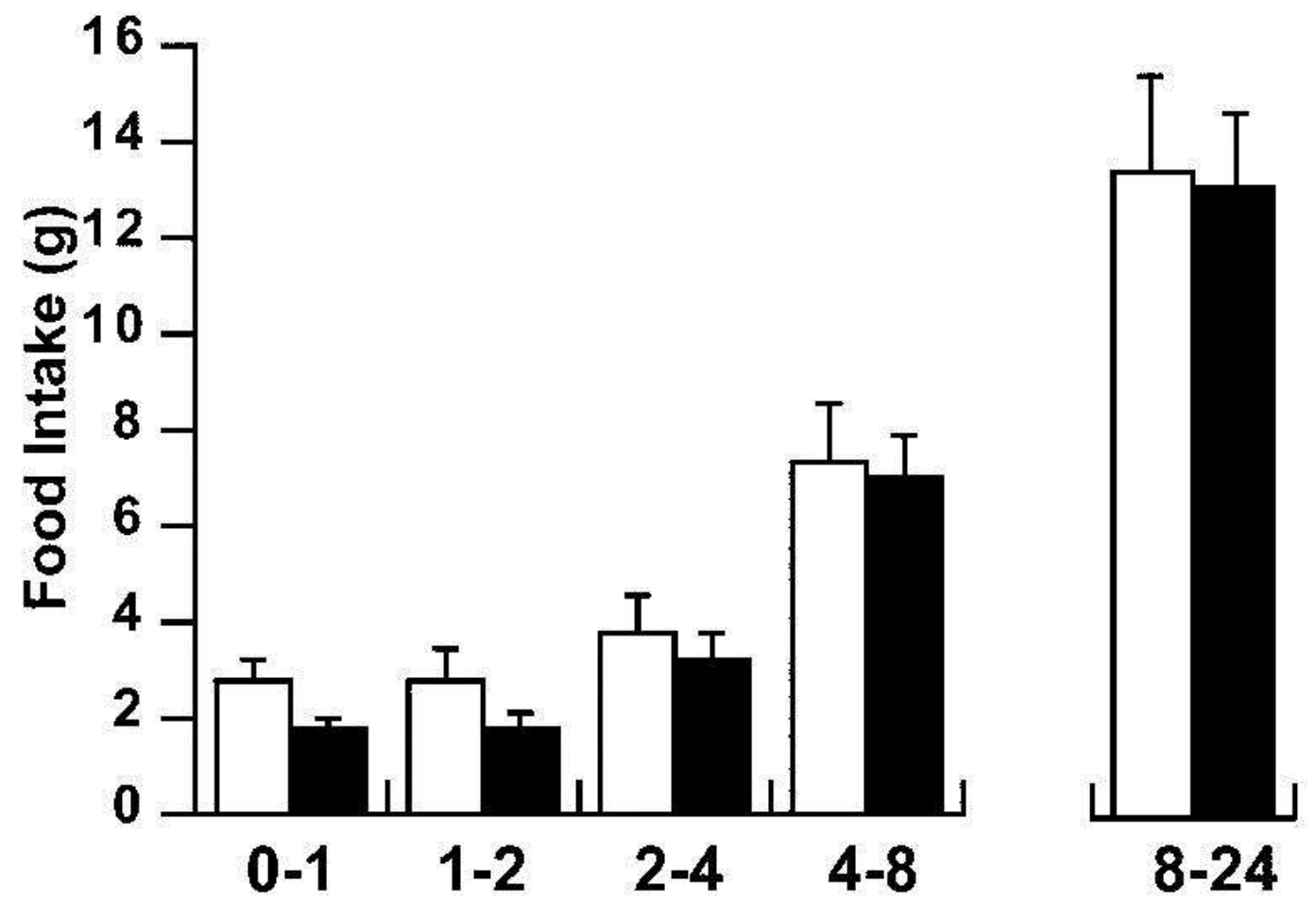

Fig 1 Time course of food intake following an acute injection of fenfluramine into the hypothalamic PVN. Feeding was suppressed 2 hours immediately after drug administration (ANOVA with repeated measures, $p<0.02$ treatment; $p<0.0001$ time). Black bars $=$ fenfluramine $(200 \mathrm{nmol} / 0.5 \mu \mathrm{l} /$ side $) ;$ white bars $=$ vehicle. $\mathrm{n}=8$ 10/group

We measured mRNA expression for several neuropeptides known to be involved in feeding at one, two, and four hours after drug injection. PVN fenfluramine injections significantly increased CRF mRNA expression (fig. 2; ANOVA, $\mathrm{p}<0.05$ for treatment) at 1 hour, but not 2 or 4 hrs post-injection $(p<0.03)$. Fenfluramine-induced increases in CRF mRNA were not accompanied by changes in plasma corticosterone concentrations (fig. 3). 
NOT THE PUBLISHED VERSION; this is the author's final, peer-reviewed manuscript. The published version may be accessed by following the link in the citation at the bottom of the page.
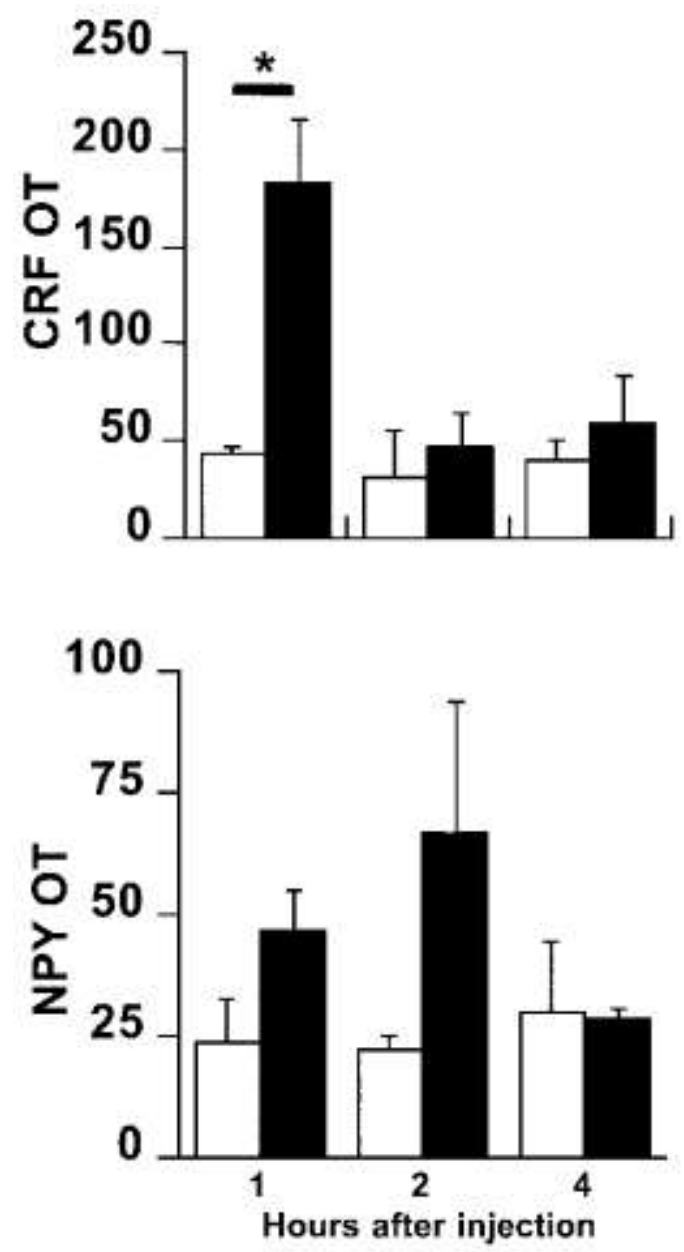

Fig 2 Dark field analysis of silver grains expressed in unit-less values of optical transmission (OT). Top, CRF mRNA levels (ANOVA, $p<0.05$ treatment); bottom, NPY mRNA levels (ANOVA, $p<0.05$ treatment) following an acute PVN injection of

fenfluramine $(200 \mathrm{nmol} / 0.5 \mu \mathrm{l} / \mathrm{side})$. Black bars = fenfluramine; white bars = vehicle; $*=\mathrm{p}<0.03$ (Fisher's test), $\mathrm{n}=4-5 /$ group. 


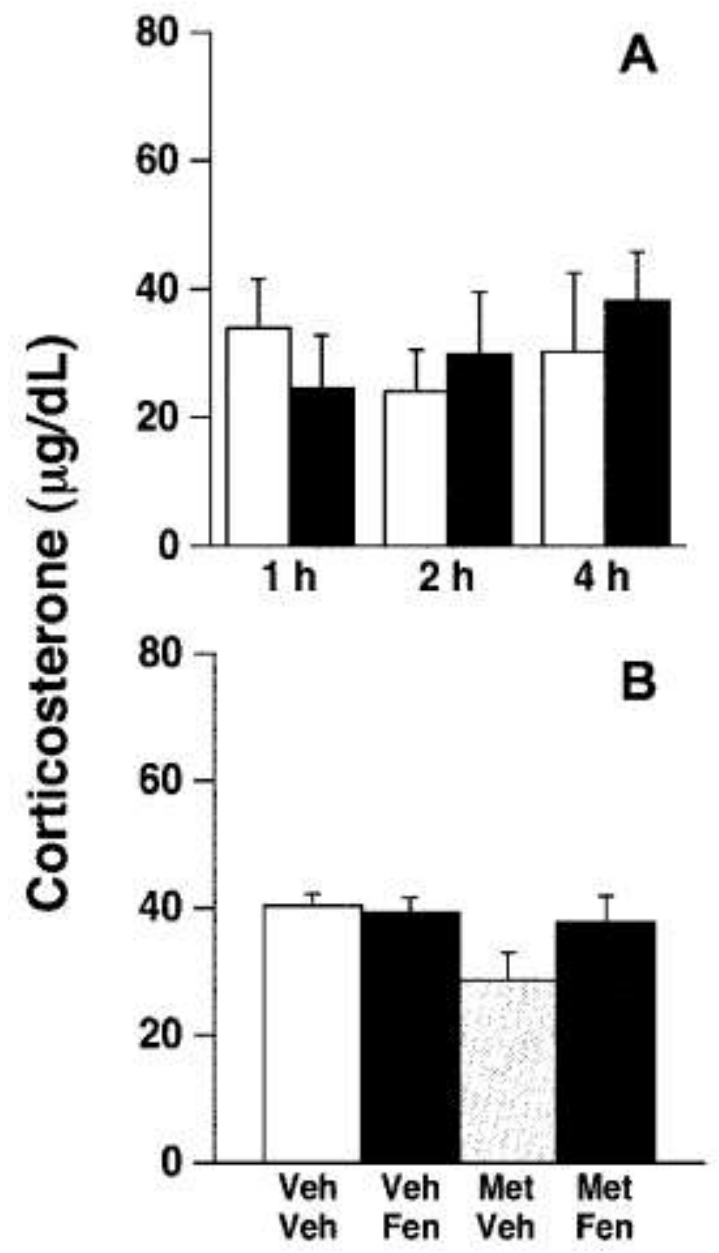

Fig 3 Plasma corticosterone levels following fenfluramine administration. No significant effects were noted in corticosterone levels after A) PVN fenfluramine administration $(200 \mathrm{nmol} / 0.5 \mu \mathrm{l} / \mathrm{side}$; black bars = fenfluramine; white bars = vehicle) or B) following metergoline (MET; $15 \mathrm{nmol} / 0.5 \mu \mathrm{l} / \mathrm{side}$ ) and/or fenfluramine (FEN) administration compared to vehicle (VEH). $n=4-5 /$ group.

PVN fenfluramine injections also significantly increased NPY mRNA expression in the arcuate nuclei (fig. 2; ANOVA, $p<0.05$ treatment effect), although post-hoc testing did not reveal specific differences at specific time points.

\section{Experiment 2 - Blocking fenfluramine action in the PVN}

Central fenfluramine administration in rats receiving no metergoline produced significant hypophagia at one hour after drug administration (Fig. 4; ANOVA, p<0.03; post-hoc, p<0.04). Metergoline did not alter feeding significantly from controls. However, metergoline administered into the PVN just prior to fenfluramine reversed the hypophagia by reducing the number of feeding bouts 
(without effects on meal size) within the first hour (fig. 4; ANOVA, $\mathrm{p}<0.02$; post-hoc, $\mathrm{p}<0.01$ ).
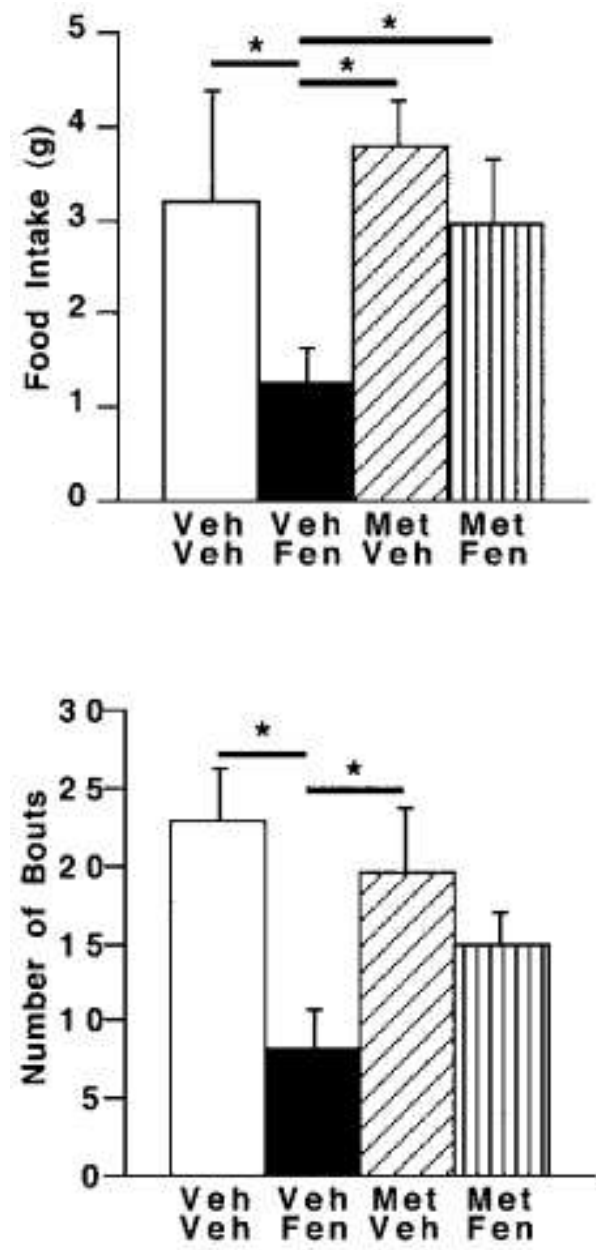

Fig 4 Levels of food intake and feeding bouts following drug administration. Metergoline (MET; $15 \mathrm{nmol} / 0.5 \mu \mathrm{l} /$ side) or vehicle (VEH) was administered into the PVN just prior to the PVN injection of fenfluramine (FEN; $200 \mathrm{nmol} / 0.5 \mu \mathrm{l} / \mathrm{side}$ ) or vehicle. A) Food intake (ANOVA, $p<0.03$, treatment effect) or B) feeding bouts (ANOVA, $\mathrm{p}<0.02$; treatment effect) were measured 1 hour after drug administration. $*=\mathrm{p}<0.04$ (Fisher's test); $\mathrm{n}=4-5 /$ group.

As in experiment 1, fenfluramine significantly altered PVN CRF mRNA expression at one hour post-injection (fig. 5a; ANOVA, p<0.02). Moreover, post-hoc analysis revealed that CRF mRNA levels in vehicle/fenfluramine-treated rats were significantly elevated over all other treatment groups (post-hoc, $\mathrm{p}<0.03$ ). Metergoline alone did not alter CRF mRNA expression compared to control values, but blocked fenfluramine-induced stimulation of PVN CRF mRNA levels. Moreover, we found no change in CRF mRNA levels in animals treated with fenfluramine with misplaced cannulae compared to controls (fig. 5a; 
miss). These treatments produced no alterations in serum corticosterone concentrations (figure 3). NPY mRNA expression in the hypothalamic arcuate nuclei was significantly increased by fenfluramine treatment; the effect was also blocked by pre-treatment with metergoline (fig. 5b; ANOVA, $p<0.02$ for treatment; post-hoc $\mathrm{p}<0.03)$. In contrast, PVN injections of any combination of fenfluramine or metergoline did not modify arcuate nuclei POMC mRNA expression (fig. 5c).
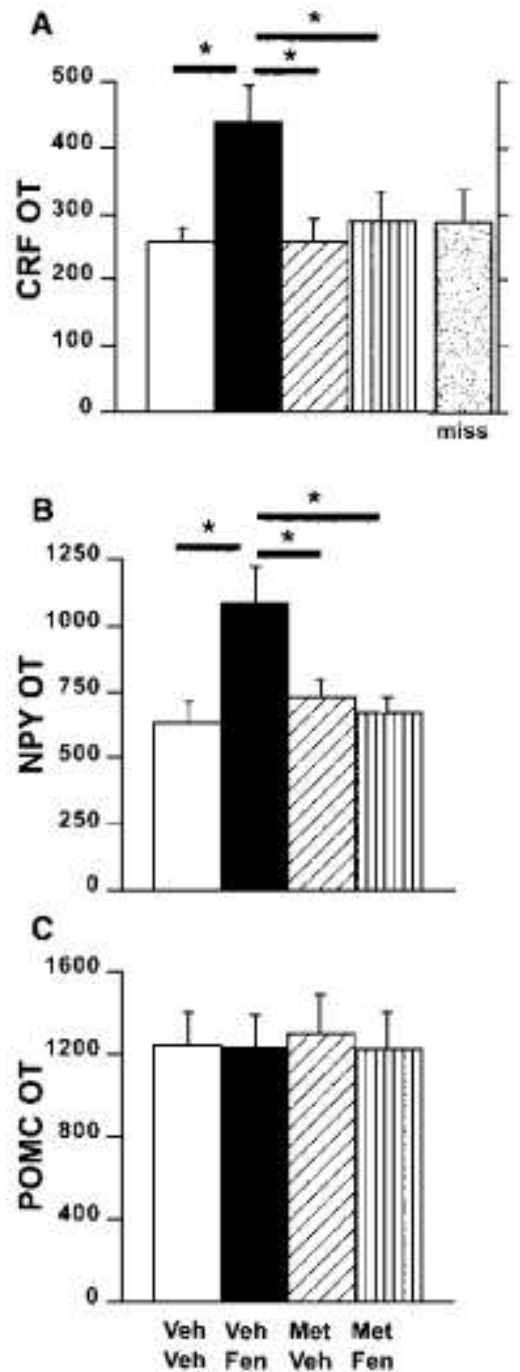

Fig 5 Hypothalamic neuropeptide mRNA levels following drug administration. Dark field analysis of silver grains expressed as levels of optical transmission (OT) of A) CRF mRNA in the PVN (ANOVA, main treatment effect $p<0.02$ ), B) NPY mRNA in the arcuate nuclei (ANOVA, main treatment effect $p<0.02$ ) and $\mathbf{C}$ ) POMC mRNA in the arcuate nuclei 1 hour after an acute injection of fenfluramine (FEN; $200 \mathrm{nmol} / 0.5$ $\mu \mathrm{l} / \mathrm{side}$ ) and/or metergoline (MET; $15 \mathrm{nmol} / 0.5 \mu \mathrm{l} / \mathrm{side}$ ). Miss = animals treated with fenfluramine but with incorrect cannulae placement. VEH $=$ vehicle. $*=p<0.03$ (Fisher's test); $n=4-5 /$ group. 
NOT THE PUBLISHED VERSION; this is the author's final, peer-reviewed manuscript. The published version may be accessed by following the link in the citation at the bottom of the page.

\section{Discussion}

Systemic administration of fenfluramine, a 5-HT releaser and reuptake inhibitor, not only decreases feeding behavior [5] but also increases both c-Fos protein and corticotropin releasing factor (CRF) mRNA expression in the hypothalamic medial dorsal paraventricular nuclei $[4,17,18]$. The effects of intraventricular administration of 5$\mathrm{HT}$ on feeding are blocked with CRF antibodies. These findings suggest CRF to be a downstream target that contributes to the anorexic response of 5-HT [19]. Serotonergic projections from brainstem raphe nuclei are found in abundance in the medial parvocellular paraventricular nuclei (PVN) where CRF neurons are concentrated [20, $29,32]$ and are known to decrease appetite. Collectively, these studies suggest the hypothalamic PVN as an important site of serotonergic regulation of feeding behavior.

Injecting fenfluramine into the PVN reduces overall food intake by reducing the number of feeding bouts at the onset of darkness when food intake levels peak. This hypophagia occurs within the first hours after drug administration and without subsequent rebound feeding. Similar studies have shown identical responses within subsets of this time frame $[19,23,36]$.

To begin identifying central neurons that respond to fenfluramine, we examined neuropeptide $Y$ (NPY) and proopiomelanocortin (POMC) in the arcuate nuclei, and CRF, which is abundantly expressed in PVN neurons. As with systemic fenfluramine $[4,15]$, CRF mRNA levels were elevated two hours after fenfluramine injections into the PVN. Evidence that intraventricular CRF significantly reduces food intake and CRF-overexpressing mice exhibit diminished hyperphagia following an overnight fast support a role for CRF signaling in the regulation of feeding behavior $[1,33]$. Although PVN CRF regulates hypothalamic-pituitary-adrenal axis (HPA) function, the increase in CRF mRNA expression levels in the current studies was not accompanied by differences in plasma corticosterone levels, perhaps suggesting that any effects of increased PVN CRF neuronal activity were either local or downstream. PVN CRF projections to the nucleus tractus solitarius may account for, in part, the effects on feeding without activation of the HPA axis [2]. Moreover, the lack of measurable corticosterone differences between treatment groups may also reflect the time of day blood was sampled. We conducted studies around dark onset to observe fenfluramine effects when rats normally eat their largest meal. This time of day plasma corticosterone levels are normally at peak diurnal concentrations with diminished responsivity to HPA stimulation [9].

Neuroscience Letters, Vol. 498, No. 3 (July 2011): pg. 213-217. DOI. This article is @ Elsevier and permission has been granted for this version to appear in e-Publications@Marquette. Elsevier does not grant permission for this article to be further copied/distributed or hosted elsewhere without the express permission from Elsevier. 
In contrast to PVN delivery of fenfluramine, systemic administration of the drug produces rapid anorexia, increased PVN CRF mRNA and a reduction in NPY mRNA expression [4, 26]. The combination of CRF stimulation and NPY inhibition may reflect independent drug actions at the paraventricular and arcuate nuclei, respectively. Conversely, fenfluramine administration into the PVN may indirectly initiate reflexive responses of appetite-stimulating signals such as NPY to counter the increasing anorexic drive produced by CRF. Within the PVN, both $5-\mathrm{HT}_{1 \mathrm{~B}}$ and $5-\mathrm{HT}_{2 \mathrm{~A}}$ receptor immunoreactivity can be found co-localized with CRF neurons, thus suggesting possible pathways of $5-\mathrm{HT}$ induced anorexia [8, 22]. A more recent study demonstrates that antagonism of $5-\mathrm{HT}_{2} \mathrm{C}$ receptors in the PVN can block systemic fenfluramine stimulation of CRF mRNA [15]. The mechanisms by which PVN CRF stimulation could regulate arcuate NPY neurons are not presently known, though projections from the PVN to the arcuate have been described [21]. In the arcuate, inhibitory $5-\mathrm{HT}_{1 \mathrm{~B}}$ receptors are found to be localized on NPY neurons [14], allowing the possibility of direct inhibition of arcuate NPY neurons by systemic fenfluramine.

The present data support the notion that fenfluramine could induce its anorectic action via a $5-\mathrm{HT}$ receptor-mediated effect on CRF neurons in the PVN. Furthermore, systemic administration of fenfluramine or specific $5-\mathrm{HT}_{1 \mathrm{~B}}, 5-\mathrm{HT}_{2 \mathrm{~A}}, 5-\mathrm{HT}_{2 \mathrm{C}}$ receptor agonists suppress food intake while selective or semi-selective antagonists block such actions $[11,13,25,34]$. Thus, we examined selective serotonin receptor subtypes within the PVN. However, since available data suggest 5-HT-mediated suppression of feeding may occur via multiple 5-HT receptor subtypes, we chose metergoline, which blocks both $5-\mathrm{HT}_{1}$ and $5-\mathrm{HT}_{2}$ receptors, for study. Indeed, studies that have employed drugs that are highly-selective for a specific 5-HT receptor subtype may be overlooking the possibility that the food intake suppression produced by a drug like fenfluramine may depend on stimulating more than a single $5-\mathrm{HT}$ receptor. Additional studies are needed to pursue whether multiple receptor subtypes are necessary to sufficiently produce fenfluramine's effects on behavior and gene expression. Our observation that metergoline in the PVN effectively blocks fenfluramine's actions on feeding behavior is consistent with studies having utilized systemic drug administration, while also offering the possibility that fenfluramine may be mediating its anorectic actions, at least in part, via a direct effect on PVN CRF neurons.

Neuroscience Letters, Vol. 498, No. 3 (July 2011): pg. 213-217. DOI. This article is C Elsevier and permission has been granted for this version to appear in e-Publications@Marquette. Elsevier does not grant permission for this article to be further copied/distributed or hosted elsewhere without the express permission from Elsevier. 
NOT THE PUBLISHED VERSION; this is the author's final, peer-reviewed manuscript. The published version may be accessed by following the link in the citation at the bottom of the page.

\section{Research Highlights}

1. Fenfluramine is a useful pharmacological tool to increase serotonin signaling

2. FEN injected directly into the PVN suppresses feeding and increases CRF MRNA

3. Prior metergoline treatment blocks FEN effects on feeding and mRNA expression

4. 5-HT - CRF interactions in the PVN may be a useful therapeutic target for weight loss

Acknowledgments: This work was supported in part by NIH Grant DK074734 to SC.

\section{Abbreviations}

$\begin{array}{ll}\text { 5-HT } & \text { serotonin } \\ \text { CRF } & \text { corticotropin releasing factor } \\ \text { NPY } & \text { neuropeptide } \mathrm{Y} \\ \text { PVN } & \text { paraventricular nuclei } \\ \text { POMC pro-opiomelanocortin } \\ \text { OT optical transmission }\end{array}$

\section{Footnotes}

Publisher's Disclaimer: This is a PDF file of an unedited manuscript that has been accepted for publication. As a service to our customers we are providing this early version of the manuscript. The manuscript will undergo copyediting, typesetting, and review of the resulting proof before it is published in its final citable form. Please note that during the production process errors may be discovered which could affect the content, and all legal disclaimers that apply to the journal pertain.

\section{References}

1. Arase K, Shargill NS, Bray GA. Effects of corticotropin releasing factor on genetically obese (fatty) rats. Physiol Behav. 1989;45:565-570.

2. Blevins JE, Eakin TJ, Murphy JA, Schwartz MW, Baskin DG. Oxytocin innervation of caudal brainstem nuclei activated by cholecystokinin. Brain Res. 2003;993:30-41.

3. Bray GA. A concise review on the therapeutics of obesity. Nutrition. 2000;16:953-960.

4. Choi S, Blake V, Cole S, Fernstrom JD. Effects of chronic fenfluramine administration on hypothalamic neuropeptide mRNA expression. Brain Res. 2006;1087:83-86.

5. Choi S, Jonak EM, Simpson L, Patil V, Fernstrom JD. Intermittent, chronic fenfluramine administration to rats repeatedly suppresses food intake

Neuroscience Letters, Vol. 498, No. 3 (July 2011): pg. 213-217. DOI. This article is @ Elsevier and permission has been granted for this version to appear in e-Publications@Marquette. Elsevier does not grant permission for this article to be further copied/distributed or hosted elsewhere without the express permission from Elsevier. 
NOT THE PUBLISHED VERSION; this is the author's final, peer-reviewed manuscript. The published version may be accessed by following the link in the citation at the bottom of the page.

despite substantial brain serotonin reductions. Brain Res. 2002;928:30-39.

6. Clemett DA, Punhani T, Duxon MS, Blackburn TP, Fone KC. Immunohistochemical localisation of the $5-\mathrm{HT} 2 \mathrm{C}$ receptor protein in the rat CNS. Neuropharmacology. 2000;39:123-132.

7. Connolly HM, Crary JL, McGoon MD, Hensrud DD, Edwards BS, Edwards WD, Schaff HV. Valvular heart disease associated with fenfluraminephentermine. N Engl J Med. 1997;337:581-588.

8. Cornea-Hebert V, Riad M, Wu C, Singh SK, Descarries L. Cellular and subcellular distribution of the serotonin $5-\mathrm{HT} 2 \mathrm{~A}$ receptor in the central nervous system of adult rat. J Comp Neurol. 1999;409:187-209.

9. Dallman MF. Viewing the ventromedial hypothalamus from the adrenal gland. Am J Physiol. 1984;246:R1-R11.

10. Garattini S, Caccia S, Mennini T, Samanin R, Consolo S, Ladinsky H. Biochemical pharmacology of the anorectic drug fenfluramine: a review. Current Medical Research and Opinion. 1979;6:15-27.

11. Grignaschi G, Sironi F, Samanin R. The 5-HT1B receptor mediates the effect of $d$-fenfluramine on eating caused by intra-hypothalamic injection of neuropeptide Y. European J Pharmacol. 1995;274:221224.

12. Grinker JA, Drewnowski A, Enns M, Kissileff H. Effects of d-amphetamine and fenfluramine on feeding patterns and activity of obese and lean Zucker rats. Pharmacol Biochem Behav. 1980;12:265-275.

13. Hayashi A, Suzuki M, Sasamata M, Miyata K. Agonist diversity in 5-HT(2C) receptor-mediated weight control in rats. Psychopharmacology (Berl) 2005; 178:241-249.

14. Heisler LK, Cowley MA, Tecott LH, Fan W, Low MJ, Smart JL, Rubinstein M, Tatro JB, Marcus JN, Holstege H, Lee CE, Cone RD, Elmquist JK. Activation of central melanocortin pathways by fenfluramine. Science. 2002;297:609-611.

15. Heisler LK, Pronchuk N, Nonogaki K, Zhou L, Raber J, Tung L, Yeo GS, O'Rahilly S, Colmers WF, Elmquist JK, Tecott LH. Serotonin activates the hypothalamic-pituitary-adrenal axis via serotonin $2 \mathrm{C}$ receptor stimulation. J Neurosci. 2007;27:6956-6964.

16. Humphrey PP, Hartig P, Hoyer D. A proposed new nomenclature for 5-HT receptors. Trends Pharmacol Sci. 1993;14:233-236.

17. Javed A, Kamradt MC, Van de Kar LD, Gray TS. D-Fenfluramine induces serotonin-mediated Fos expression in corticotropin-releasing factor and oxytocin neurons of the hypothalamus, and serotonin-independent Fos expression in enkephalin and neurotensin neurons of the amygdala. Neuroscience. 1999;90:851-858.

18. Laflamme N, Bovetto S, Richard D, Rivest S. Effect of dexfenfluramine on the transcriptional activation of CRF and its type 1 receptor within the paraventricular nucleus of the rat hypothalamus. British Journal of Pharmacology. 1996;117:1021-1034.

19. Le Feuvre RA, Aisenthal L, Rothwell NJ. Involvement of corticotrophin releasing factor (CRF) in the thermogenic and anorexic actions of serotonin (5-HT) and related compounds. Brain Res. 1991;555:245250.

Neuroscience Letters, Vol. 498, No. 3 (July 2011): pg. 213-217. DOI. This article is (C) Elsevier and permission has been granted for this version to appear in e-Publications@Marquette. Elsevier does not grant permission for this article to be further copied/distributed or hosted elsewhere without the express permission from Elsevier. 
20. Liposits Z, Phelix C, Paull WK. Synaptic interaction of serotonergic axons and corticotropin releasing factor (CRF) synthesizing neurons in the hypothalamic paraventricular nucleus of the rat. A light and electron microscopic immunocytochemical study. Histochemistry. 1987;86:541-549.

21. Luiten PGM, Ter Horst GJ, Steffens AB. The hypothalamus, intrinsic connections and outflow pathways to the endocrine system in relation to the control of feeding and metabolism. Prog Neurobiology. $1987 ; 28: 1-54$.

22. Makarenko IG, Meguid MM, Ugrumov MV. Distribution of serotonin 5hydroxytriptamine $1 \mathrm{~B}(5-\mathrm{HT}(1 \mathrm{~B}))$ receptors in the normal rat hypothalamus. Neurosci Lett. 2002;328:155-159.

23. Max JP, Thystere P, Chapleur-Chateau M, Burlet A, Nicolas JP, Burlet C. Hypothalamic neuropeptides could mediate the anorectic effects of fenfluramine. Neuroreport. 1994;5:1925-1928.

24. McGuirk J, Goodall E, Silverstone T, Willner P. Differential effects of dfenfluramine, I-fenfluramine and d-amphetamine on the microstructure of human eating behaviour. Behav Pharmacol. 1991;2:113-119.

25. Neill JC, Cooper SJ. Evidence that d-fenfluramine anorexia is mediated by 5-HT1 receptors. Psychopharmacology (Berl) 1989;97:213-218.

26. O'Shea RD, Gundlach AL. Lack of direct action of D-fenfluramine on arcuate preproNPY mRNA levels in the rat. Neuroreport. 1994;5:21132116.

27. Paxinos G, Watson C. The rat brain in stereotaxic coordinates. Elsevier Academic Press; Amsterdam; Boston: 2007.

28. Ramos EJ, Meguid MM, Campos AC, Coelho JC, Neuropeptide Y. alphamelanocyte-stimulating hormone, and monoamines in food intake regulation. Nutrition. 2005;21:269-279.

29. Sawchenko PE, Swanson LW, Steinbusch HW, Verhofstad AA. The distribution and cells of origin of serotonergic inputs to the paraventricular and supraoptic nuclei of the rat. Brain Res. $1983 ; 277: 355-360$.

30. Schwartz MW, Woods SC, Porte D, Seeley RJ, Baskin DG. Central nervous system control of food intake. Nature. 2000;404:661-671.

31. Simansky KJ. Serotonergic control of the organization of feeding and satiety. Behav Brain Res. 1996;73:37-42.

32. Steinbusch HW. Distribution of serotonin-immunoreactivity in the central nervous system of the rat-cell bodies and terminals. Neuroscience. $1981 ; 6: 557-618$.

33. Stengel A, Goebel M, Million M, Stenzel-Poore MP, Kobelt $P$, Monnikes $H$, Tache $Y$, Wang $L$. Corticotropin-releasing factor-overexpressing mice exhibit reduced neuronal activation in the arcuate nucleus and food intake in response to fasting. Endocrinology. 2009;150:153-160.

34. Vickers SP, Dourish CT, Kennett GA. Evidence that hypophagia induced by $\mathrm{d}$-fenfluramine and d-norfenfluramine in the rat is mediated by $5-\mathrm{HT} 2 \mathrm{C}$ receptors. Neuropharmacology. 2001;41:200-209.

35. Weiss GF, Papadakos P, Knudson K, Leibowitz SF. Medial hypothalamic serotonin: effects on deprivation and norepinephrine-induced eating, Pharmacology. Biochemistry \& Behavior. 1986;25:1223-1230.

Neuroscience Letters, Vol. 498, No. 3 (July 2011): pg. 213-217. DOI. This article is (C) Elsevier and permission has been granted for this version to appear in e-Publications@Marquette. Elsevier does not grant permission for this article to be further copied/distributed or hosted elsewhere without the express permission from Elsevier. 
NOT THE PUBLISHED VERSION; this is the author's final, peer-reviewed manuscript. The published version may be accessed by following the link in the citation at the bottom of the page.

36. Weiss GF, Rogacki N, Fueg A, Buchen D, Leibowitz SF. Impact of hypothalamic d-norfenfluramine and peripheral $d$ - fenfluramine injection on macronutrient intake in the rat. Brain Research Bulletin. $1990 ; 25: 849-859$. 